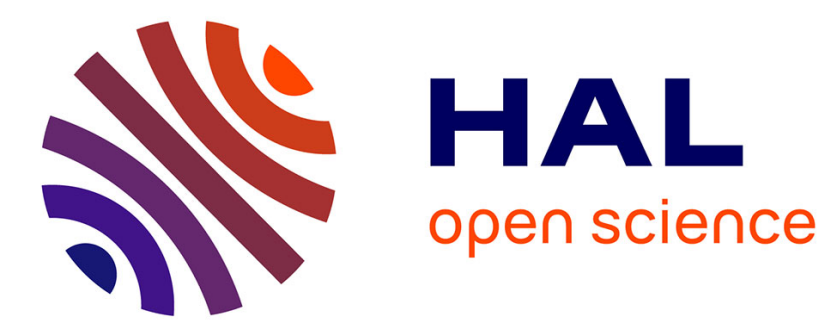

\title{
Hydration Degree of Alkali-Activated Slags: A 29Si NMR Study
}

Gwenn Le Saoût, Mohsen Ben Haha, Frank Winnefeld, Barbara Lothenbach

\section{To cite this version:}

Gwenn Le Saoût, Mohsen Ben Haha, Frank Winnefeld, Barbara Lothenbach. Hydration Degree of Alkali-Activated Slags: A 29Si NMR Study. Journal of the American Ceramic Society, 2011, 94 (12), pp.4541-4547. 10.1111/j.1551-2916.2011.04828.x . hal-03250539

\section{HAL Id: hal-03250539 https://hal.science/hal-03250539}

Submitted on 4 Jun 2021

HAL is a multi-disciplinary open access archive for the deposit and dissemination of scientific research documents, whether they are published or not. The documents may come from teaching and research institutions in France or abroad, or from public or private research centers.
L'archive ouverte pluridisciplinaire HAL, est destinée au dépôt et à la diffusion de documents scientifiques de niveau recherche, publiés ou non, émanant des établissements d'enseignement et de recherche français ou étrangers, des laboratoires publics ou privés. 


\title{
Hydration Degree of Alkali-Activated Slags: A ${ }^{29}$ Si NMR Study
}

\author{
Gwenn Le Saoût, ${ }^{\dagger}$ Mohsen Ben Haha, Frank Winnefeld, and Barbara Lothenbach \\ Empa, Swiss Federal Laboratories for Materials Science and Technology, Concrete and Construction Chemistry Laboratory, \\ Überlandstrasse 129, CH-8600, Dübendorf, Switzerland
}

\begin{abstract}
A commercial blast furnace slag was activated using either sodium hydroxide or hydrous sodium metasilicate, and the degree of hydration was determined by ${ }^{29} \mathrm{Si}$ magic angle spinning nuclear magnetic resonance (NMR). The results are compared with measurements made using scanning electron microscopy image analysis (SEM-IA). The results from both ${ }^{29} \mathrm{Si}$ NMR and the SEM-IA measurements indicated a fast initial reaction with the alkali, and similar degrees of hydration throughout the reaction. The ${ }^{29} \mathrm{Si}$ NMR results were analyzed using two different methods for fitting the residual slag in the decomposition of the ${ }^{29} \mathrm{Si}$ NMR spectra: the first method used the spectrum of the anhydrous slag, whereas the second method used the spectrum of the dissolution residue of the hydrated sample. Only the first method provided a satisfactory simulation. The degree of hydration and the $\mathrm{Al} / \mathrm{Si}$ atomic ratio within the $\mathrm{C}-\mathrm{S}-\mathrm{H}$, deduced by ${ }^{29} \mathrm{Si} \mathrm{NMR}$ were in agreement with SEM-IA and EDX analyses.
\end{abstract}

\section{Introduction}

$\mathrm{T}$ HE use of industrial byproducts, such as blast furnace slag, activated in an alkaline solution, shows great promise as replacements for Portland cement, the primary binder used in concrete. ${ }^{1,2}$ Before these replacement materials can be used routinely, however, the hydration process must be understood sufficiently so that important engineering properties, such as strength and setting time, can be predicted and controlled on an industrial scale. The chemical composition of the alkaline activator and the slag are the most important factors in the development of high and early strength. ${ }^{3,4}$ The reactivity of the slag is critical to controlling the physical and chemical properties of the hydrated slag. The main reaction products of alkali-activated slag are calcium silicate hydrate $(\mathrm{C}-\mathrm{S}-\mathrm{H})$ with a $\mathrm{Ca} / \mathrm{Si}$ atomic ratio near 1 , and a hydrotalcite-like phase. ${ }^{4-8}$ As the reaction between the slag and the alkali activator progress, the fraction of the slag that has reacted corresponds to the degree of hydration $(\mathrm{DOH})$. Determining the DOH is difficult because both the slag and the $\mathrm{C}-\mathrm{S}-\mathrm{H}$ are largely amorphous, and have similar chemical composition. There are, however, number of different methods for determining the DOH: selective dissolution of the hydrated products, ${ }^{9}$ scanning electron microscopy image analysis (SEM-IA), ${ }^{4}$ and ${ }^{29} \mathrm{Si}$ nuclear magnetic resonance (NMR). ${ }^{5}$

Each of these methods has both strengths and weakness. The extraction method is known to give poor results in the determination of the $\mathrm{DOH}$ due to the presence of insoluble hydrotalcite-like phase. A significant proportion of the unreacted slag may also dissolve in the reagent. ${ }^{10}$ Alternatively,

C. Jantzen — contributing editor

\footnotetext{
Manuscript No. 29278. Received February 02, 2011; approved July 27, 2011.

'Author to whom correspondence should be addressed. e-mail: gwenn.lesaout@ empa.ch.
}

${ }^{29} \mathrm{Si}$ NMR can be used to determine the percentages of slag reacted in alkali-activated slags ${ }^{11}$ or in blended cements. ${ }^{12} \mathrm{An}$ earlier study that compared the extent of reaction measured by image analysis of backscattered electron images and ${ }^{29} \mathrm{Si}$ $\mathrm{NMR}^{13}$ suffered from significant drying shrinkage during specimen preparation for SEM-IA, which led to an underestimation of the slag DOH. ${ }^{13}$ As a result, there was a poor agreement between extent of reaction deduced from NMR and that deduced from SEM-IA (respectively, 72 and $64 \mathrm{wt} \%$ ). ${ }^{13}$ Recently, Ben Haha et al. obtained backscattered images without microcracks (due to drying shrinkage) and were able to quantitate the DOH of fly ash in blended cements ${ }^{14}$ and the DOH of slag in alkali-activated blast furnace slags. ${ }^{3,4}$

To obtain the $\mathrm{DOH}$ from ${ }^{29} \mathrm{Si}$ NMR experiments, one needs to simulate the NMR spectra so that one can decompose the constituents. Determining the individual Si chemical shifts by spectral decomposition is difficult because the position of the slag chemical shift overlaps the $\mathrm{C}-\mathrm{S}-\mathrm{H}$ chemical shift. ${ }^{16}$ Dyson et al. ${ }^{15}$ proposed two methods to overcome this problem. The first one involved the manual fitting of residual slag using the spectrum of the anhydrous slag. ${ }^{17}$ This method assumes a congruent dissolution of the slag. Regourd et al. ${ }^{18}$ showed, however, that the surface of a slag is modified as soon as it comes into contact with water. The glassy phase richest in $\mathrm{Ca}$ and $\mathrm{Al}$, has the greatest tendency to dissolve. The first silica elements to dissolve are $\left(\mathrm{SiO}_{4}\right)^{-4}\left(\mathrm{Q}^{0}\right)$, $\left(\mathrm{SiO}_{3.5}\right)^{-3}\left(\mathrm{Q}^{1}\right)$ so that the surface layer of the slag is enriched in less basic components, such as $\left(\mathrm{SiO}_{3}\right)^{-2}\left(\mathrm{Q}^{2}\right)$ and $\left(\mathrm{SiO}_{2.5}\right)^{-}$ $\left(\mathrm{Q}^{3}\right)$. After this initial step, the slag dissolution becomes congruent. ${ }^{19}$ Dyson et al. ${ }^{15}$ showed that a meaningful fit was not possible in their hydrated blast furnace slag cement blends using this method, probably due to a change in the initial peak shape of the slag. The second method involved the manual fitting of residual slag using the spectrum of the dissolution residue to represent the peak shape of the slag. However, the authors observed the presence of an aluminosilicate gel that may be a byproduct of the dissolution process or a true product of slag hydration. The presence of such aluminosilicate gel could affect the NMR spectrum.

In this study, these two NMR methods are applied to a simple system composed of an alkali-activated slag using two different activators: sodium hydroxide $(\mathrm{NaOH})$ and hydrous sodium metasilicate $\left(\mathrm{Na}_{2} \mathrm{SiO}_{3} \cdot 5 \mathrm{H}_{2} \mathrm{O}\right)$. The results are compared with the DOH determined by SEM-IA.

\section{Experimental Details}

The slag chosen for this experiment was from a commercial supplier and the composition of the slag is shown in Table I; the slag is given the designation M13 because it contains $13 \mathrm{wt} \% \mathrm{MgO}$. This slag has been previously used in a study of the influence of $\mathrm{MgO}$ content on the hydration of alkaliactivated slags. ${ }^{3}$ Two activators, $3.8 \mathrm{wt} \%$ sodium hydroxide (labeled as $\mathrm{NaOH}$ ) and $10.0 \mathrm{wt} \%$ hydrous sodium metasilicate $\mathrm{Na}_{2} \mathrm{SiO}_{3} \cdot 5 \mathrm{H}_{2} \mathrm{O}$ (commonly referred to as water glass, and labeled $\mathrm{WG}$ ) were used, with the weight percent chosen to achieve the same $\mathrm{Na}_{2} \mathrm{O}$ content in each mixture. The activators were dissolved in water $24 \mathrm{~h}$ prior to mixing, 
Table I. Composition of the Slag M13

\begin{tabular}{lc}
\hline Chemical analyses $(\mathrm{wt} \%)^{\dagger}$ & Slag M13 \\
\hline Ignition loss $\left(950^{\circ} \mathrm{C}\right)$ & -0.4 \\
$\mathrm{SiO}_{2}$ & 36.4 \\
$\mathrm{CaO}$ & 33.4 \\
$\mathrm{MgO}$ & 13.2 \\
$\mathrm{Al}_{2} \mathrm{O}_{3}$ & 11.3 \\
$\mathrm{Mn}_{2} \mathrm{O}_{3}$ & 1.4 \\
$\mathrm{Fe}_{2} \mathrm{O}_{3}$ & 1.4 \\
$\mathrm{~K}_{2} \mathrm{O}$ & 1.0 \\
$\mathrm{Na}_{2} \mathrm{O}$ & 0.5 \\
$\mathrm{TiO}_{2}$ & 0.5 \\
$\mathrm{P}_{2} \mathrm{O}_{5}$ & 0.02 \\
$\mathrm{Total}_{\text {density }}\left(\mathrm{g} / \mathrm{cm}^{3}\right)$ & 99.0 \\
$\mathrm{den}^{3}$ & 2.94 \\
Xase composition $(\mathrm{wt} \%)^{\ddagger}$ & \\
X-ray amorphous & 98.5 \\
Merwinite & 1.3 \\
Melilite & 0.2
\end{tabular}

${ }^{\dagger}$ XRF data.

${ }^{\ddagger}$ From Rietveld analysis (see ref. 3 for details).

sealed in jars, and stored at $23^{\circ} \mathrm{C}$. The pastes were formulated to have water to binder mass ratio of 0.4 , and were mixed using a high shear blender. The fresh paste was poured into plastic bottles of $12 \mathrm{~mL}$ until completely filled; the bottles were sealed, and then stored at $23^{\circ} \mathrm{C}$. Prior to the analyses by NMR, hydration was stopped after $1,7,28$, and 100 days by submerging small pieces, each $\sim 2-3 \mathrm{~mm}^{3}$, for $30 \mathrm{~min}$ in about $50 \mathrm{~mL}$ isopropanol and rinsing twice with diethylether.

The ${ }^{29} \mathrm{Si}$ magic angle spinning (MAS) NMR spectra were recorded on a Bruker Avance 400 NMR spectrometer (field strength of 9.4 T; Bruker Biospin AG, Fällanden, Switzerland) at $79.49 \mathrm{MHz}$ applying $4.5 \mathrm{kHz}$ spinning rates on a $7-\mathrm{mm} \mathrm{CP}$ MAS probe using $\mathrm{ZrO}_{2}$ rotors. Single-pulse experiments were carried out by applying $90^{\circ}$ pulses of $8.8 \mu$ s with ${ }^{1} \mathrm{H}$ decoupling of $31.3 \mathrm{kHz}$ (TPPM15) and recycle delays of $4 \mathrm{~s}$ to allow for the relaxation time $T_{1}$ of the species present in the samples (a $T_{1}$ of less than $1 \mathrm{~s}$ was determined for the slag by a $T_{1}$ saturation recovery experiment). The ${ }^{29} \mathrm{Si}$ chemical shift was referenced externally relative to tetramethylsilane at $0.0 \mathrm{ppm}$. The observed ${ }^{29} \mathrm{Si}$ resonances were analyzed using the $\mathrm{Q}^{\mathrm{n}}(m \mathrm{Al})$ classification, where one $\mathrm{Si}$ tetrahedron is connected to $n \mathrm{Si}$ tetrahedral with $n$ varying from 0 to $4 ; m$ is the number of neighboring $\mathrm{AlO}_{4}$ tetrahedra. The relative proportions of silicon associated with the $\mathrm{Q}^{n}$ units were determined by the decomposition of the spectra using the Dmfit program. ${ }^{20}$ The full procedure is outlined in the results section. The DOH referred to the ignited weight is calculated according to Eq. (1):

$$
\mathrm{DOH}=100\left(1-I_{\text {slag }}^{\mathrm{rel}}\right)
$$

where $\mathrm{I}_{\text {slag }}^{\text {rel }}$ is the relative ${ }^{29} \mathrm{Si}$ NMR intensity from the unreacted slag. This equation must be modified for the water glass to take into account the silicon from the activator:

$$
\left.\mathrm{DOH}=100\left[1-I_{\mathrm{RMN}}(t) * 1+\frac{y}{x} * \frac{\mathrm{WG}_{\mathrm{SiO}_{2}}}{\mathrm{Slag}_{\mathrm{SiO}_{2}}}\right)\right]
$$

where $y / x$ is the ignited mass ratio between the activator and the slag (0.06), $\mathrm{WG}_{\mathrm{SiO} 2}(49.2 \mathrm{wt} \%)$ and $\mathrm{Slag}_{\mathrm{SiO} 2}(36.4 \mathrm{wt} \%)$ are the relative amount of $\mathrm{SiO}_{2}$ in the water glass and in the slag, respectively.

The mean chain length and the $\mathrm{Al} / \mathrm{Si}$ atomic ratio of the $\mathrm{C}-\mathrm{S}-\mathrm{H}$ are calculated as described by Richardson et al. $^{5}$

The ${ }^{27} \mathrm{Al}$ MAS NMR spectra were obtained at 104.26 MHz on a 2.5-mm CP MAS probe using the above- mentioned NMR system. Single-pulse experiments were carried out at $20 \mathrm{kHz}$ spinning rates by applying single-pulse $(\pi / 12)$ excitation pulses of $0.5 \mu \mathrm{s}$ and $0.5 \mathrm{~s}$ relaxation delays. The ${ }^{27} \mathrm{Al}$ chemical shifts were referenced relative to a $1.0 \mathrm{~mol} / \mathrm{L} \mathrm{AlCl}_{3}-6 \mathrm{H}_{2} \mathrm{O}$ solution at $0.0 \mathrm{ppm}$.

To study the changes occurring in the unhydrated slag during hydration, two different selective dissolution methods were used. In the first method, the hydration products were removed according to the method originally proposed by Demoulian et al., ${ }^{21}$ refined by Luke and Glasser ${ }^{9}$ and further modified by Dyson et al. ${ }^{15}$ This method involves the mixing of $125 \mathrm{~mL}$ of $0.05 \mathrm{~mol} / \mathrm{L}$ EDTA di-sodium salt and $125 \mathrm{~mL}$ of $\mathrm{mol} / \mathrm{L} \mathrm{Na}_{2} \mathrm{CO}_{3}$ in a 1-L flask. To this, $12.5 \mathrm{~mL}$ of a $1: 1$ triethanolamine: water (by volume) mixture was added and the $\mathrm{pH}$, checked to be 11.6 to assure complete dissolution. Dissolution was achieved by adding $0.25 \mathrm{~g}$ of the ground sample $(<64 \mu \mathrm{m})$ to the solution, followed by continuous shaking for $30 \mathrm{~min}$. The suspension was then filtered under vacuum using a GF/C filter paper and washed with deionized water and methanol. The filter paper and contents were placed in an oven at $105^{\circ} \mathrm{C}$ until a constant weight was reached.

In addition, a second selective dissolution method was used, where the ground sample was added to a $1 \mathrm{wt} \%$ aqueous solution of dimethyl formamide (DMF). The DMF is thought to reduce the precipitation of silica gel by keeping the silica in solution. ${ }^{22}$ After 30 min of continuous shaking, the suspension is processed as described above.

For the microscopical investigations, slices of hydrated samples were cut, immediately immersed in isopropanol, and then subsequently dried at $40^{\circ} \mathrm{C}$ for $24 \mathrm{~h}$. Afterward, they were impregnated using a low viscosity epoxy and polished down to $0.25 \mu \mathrm{m}$ using diamond pastes. The samples were further coated with carbon $(\sim 5 \mathrm{~nm})$ and examined using a Philips FEG-XL30 scanning electron microscope (FEI, Hillsboro, OR) coupled to energy dispersive X-ray spectroscopy (EDX) analyzer from EDAX. Backscattered electron images (BSE) were analyzed quantitatively to determine $\mathrm{DOH}$ at different hydration times using image analysis (IA). ${ }^{14,24}$ Over 80 images were taken across a polished section of a $20-\mathrm{mm}$ diameter sample. The screen magnification $(1024 \times 800$ pixels $)$ was $1.0 \mu \mathrm{m} /$ pixel. The technique uses the gray level histogram segmentation to determine the different phases observed in a BSE image. ${ }^{14,23-25}$ The sensitivity of BSE to the chemical composition of the analyzed materials leads to the phase contrast in the gray level histogram observed in BSE images. The higher the average atomic number of a phase, the greater the BSE pixel intensity. Therefore, the different phases can be distinguished by dividing the BSE histogram into distinct intensity ranges. The densest phases (unreacted slag) are the brightest, whereas less dense phases (porosity) are the darkest in the image. The reaction of the anhydrous slag is measured by comparing the volume of the anhydrous slag in the hydrated pastes with the slag content in the unhydrated pastes prior to the mixing. The measurement uncertainty is based on the threshold and edge detection, as well as accounting for the initial $2-3 \%$ porosity within the mixes.

The EDX point analyses were used to determine the elemental compositions of the hydrate assemblage. The analyses were carried out using an accelerating voltage of $15 \mathrm{kV}$ to ensure a good compromise between spatial resolution and adequate excitation of the $\mathrm{FeK}_{\alpha}$ peak. Over 60 points (EDX spots) per sample at each studied age were analyzed.

The degree of hydration is calculated by equation 3 :

$$
\left.\mathrm{DOH}=100 \quad 1-\frac{V_{\mathrm{f}}^{\mathrm{slag}}(t)}{V_{\mathrm{f}}^{\mathrm{slag}}(t=0)}\right)
$$

where $V_{\mathrm{f}}^{\text {slag }}(t)$ is the volume fraction of the slag deduced from SEM-IA at the time $t$ and $V_{\mathrm{f}}^{\text {slag }}(t=0)$ is the volume fraction of the slag calculated from the initial composition. 


\section{Results and Discussion}

\section{(1) Hydration Products}

The ${ }^{29} \mathrm{Si}$ MAS NMR spectra of the activated slags at different hydration times are presented in Fig. 1. The signal of the anhydrous slag near $-74 \mathrm{ppm}$ is present in all samples. As previously shown for $\mathrm{NaOH}$-activated slags, ${ }^{17,26}$ the spectra contain three well-defined resonances from $\mathrm{C}-\mathrm{S}-\mathrm{H}$ near $-78,-81$, and $-84 \mathrm{ppm}$, respectively, assigned to $\mathrm{Q}^{1}, \mathrm{Q}^{2}(1 \mathrm{Al})$, and $\mathrm{Q}^{2}$ species. The ${ }^{29} \mathrm{Si}$ NMR spectra for slag activated with $\mathrm{WG}$ are similar to those for slag activated with $\mathrm{NaOH}$, but with a broadening of the peaks, as already observed, ${ }^{7,27}$ reflecting an increase in disorder in the $\mathrm{C}-\mathrm{S}-\mathrm{H}$ structure (higher distribution of $\mathrm{Si}-\mathrm{O}$ bond lengths and $\mathrm{Si}-\mathrm{O}-\mathrm{Si}$ angles). For a given activator, we obtain similar spectra after different reaction times, with the exception of the 1-day sample activated with $\mathrm{NaOH}$, where the relative amount of $\mathrm{Q}^{1}$ species was more pronounced. This indicates a similar $\mathrm{DOH}$ of the slag and a similar mean chain length of the $\mathrm{C}-\mathrm{S}-\mathrm{H}$ after 2 days and longer for a given activator.

Based on XRD and SEM-EDS analyses, a hydrotalcitelike phase and the $\mathrm{C}-\mathrm{S}-\mathrm{H}$ are the only hydration products observed. ${ }^{3}$ The ${ }^{27} \mathrm{Al}$ MAS NMR spectrum of synthetic hydrotalcite reveals a single peak ${ }^{28}$ that corresponds to the peak observed at around 9 ppm for the activated slags as shown in Fig. 2. We observed a broadening of this peak with the WG activator that reveals a lower crystallinity of the hydrotalcite phase. The small shoulder at around $3.5 \mathrm{ppm}$ observed in the spectrum of the WG-activated slag after 100 days of hydrolysis is related to an $\mathrm{Al}(\mathrm{VI})$ site. Two hypotheses may be found in literature to explain this peak:

1. An amorphous aluminate phase precipitates at the surface of a C-S-H (peak around $5 \mathrm{ppm})^{30}$ or precipitates as separate phase (this hypothesis is well-supported both by $\mathrm{NMR}^{39}$ and $\mathrm{TEM}^{11}$ data), and

2. Al located into the interlayer region of the $\mathrm{C}-\mathrm{S}-\mathrm{H}$ (evident as a peak near $3 \mathrm{ppm}){ }^{29}$

The ${ }^{27} \mathrm{Al}$ NMR spectra also show signals in the Al(IV) range near $65 \mathrm{ppm}$ from $\mathrm{Al}$ substituting $\mathrm{Si}$ bridging sites in the $\mathrm{C}-\mathrm{S}-\mathrm{H} .{ }^{31}$ As already noted by Schneider et al., ${ }^{32}$ an additional sharper resonance can be observed around

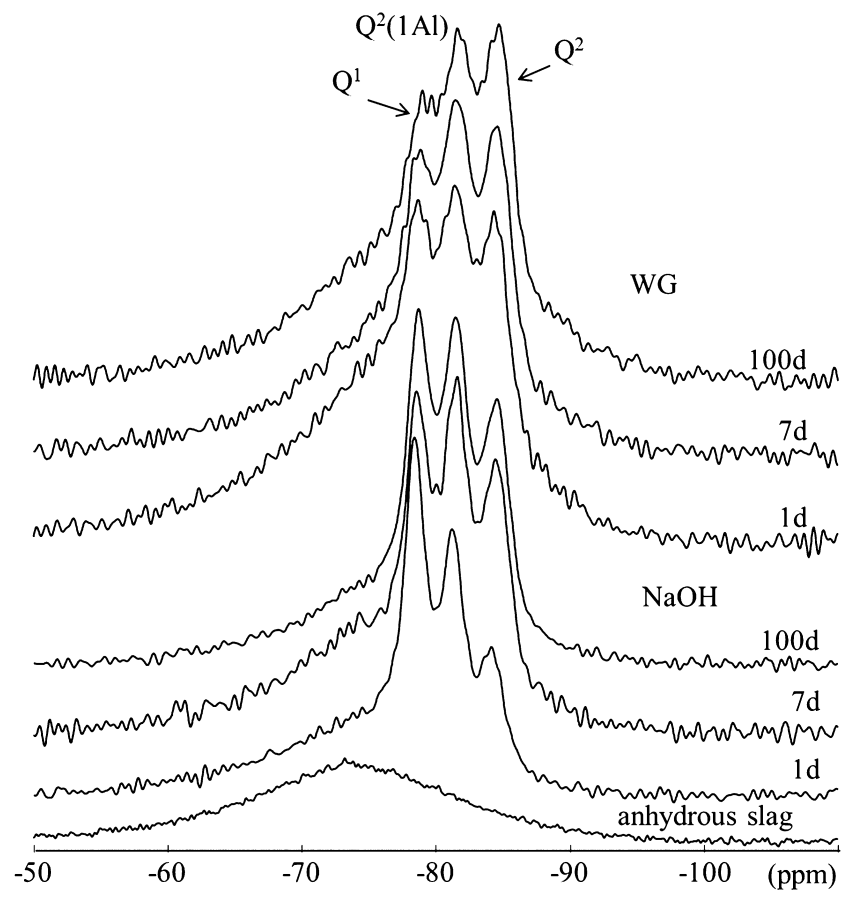

Fig. 1. ${ }^{29} \mathrm{Si}$ MAS NMR spectra of the anhydrous slag, and the $\mathrm{NaOH}$ and WG-activated slags as a function of hydration time.
$72 \mathrm{ppm}$ in the $\mathrm{NaOH}$-activated samples. In the case of $\mathrm{NaOH}$ activator, two types of $\mathrm{C}-\mathrm{S}-\mathrm{H}$ with similar $\mathrm{Ca} / \mathrm{Si}$ atomic ratio around 1 are observed by SEM and XRD, ${ }^{3,4}$ (i) a $\mathrm{C}-\mathrm{S}-\mathrm{H}$ similar to that observed with the $\mathrm{WG}$ activator and (ii) a more ordered $\mathrm{C}-\mathrm{S}-\mathrm{H}$ with a more pronounced nanometric size of the coherent domain. The sharper signal at $72 \mathrm{ppm}$ for the $\mathrm{NaOH}$ activator may be attributed to the $\mathrm{Al}$ substituting $\mathrm{Si}$ bridging site in the more ordered $\mathrm{C}-\mathrm{S}-\mathrm{H}$.

\section{(2) Decomposition of ${ }^{29} \mathrm{Si}$ MAS NMR Spectra}

The ${ }^{29} \mathrm{Si}$ MAS NMR spectrum of the unhydrated slag is presented in Fig. 3 and can be simulated by a pseudo-Voigt line shape with a mixing parameter $\eta$ of $0.3(\eta=0$ for a Lorentzian and $\eta=1$ for a Gaussian line shape) centered at $-74 \mathrm{ppm}$ with a full width at half maximum (FWHM) of $\sim 19$ ppm. By comparison, the spectra of the dissolution residue after the selective extraction procedures, which should correspond to the unhydrated fraction of the slag after 1 day, is also displayed (Fig. 3). Although the shape of the dissolution residue is different from the unhydrated slag, the signal of the dissolution residue, as well as the amount of

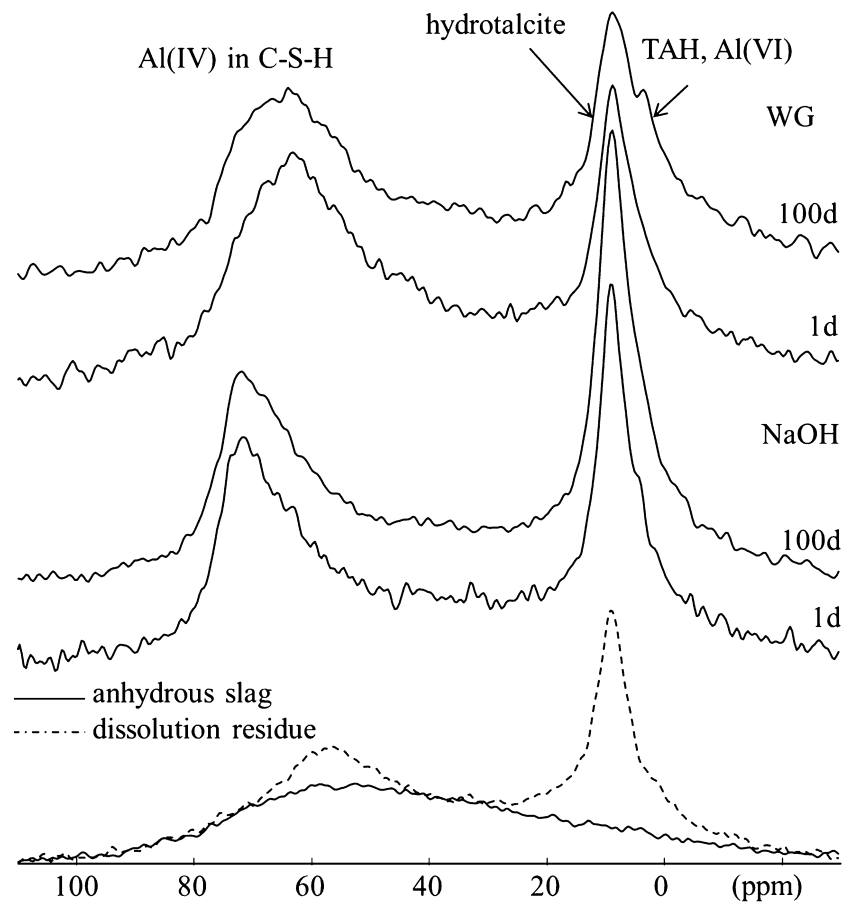

Fig. 2. ${ }^{27} \mathrm{Al}$ MAS NMR spectra of $\mathrm{NaOH}$ and WG-activated slag as a function of hydration time, anhydrous slag, and the dissolution residue of $\mathrm{NaOH}$-activated slag after 1 day of hydration.

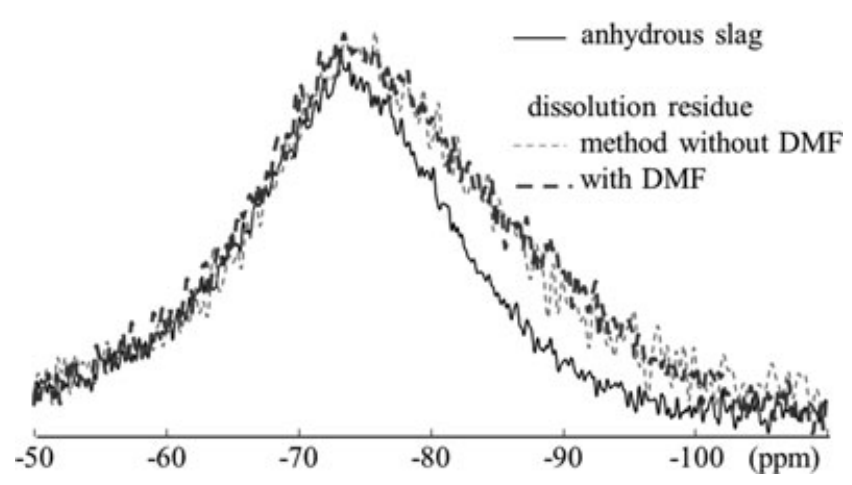

Fig. 3. ${ }^{29} \mathrm{Si}$ MAS NMR spectra of anhydrous slag and dissolution residues isolated with and without using dimethyl formamide (DMF) of $\mathrm{NaOH}$-activated slag after 1 day of hydration. 
the residue after dissolution are similar for both activators (the spectra of the water-glass-activated slag is not shown). Also, the use of DMF in the dissolution procedure does not influence the NMR spectra indicating that the use of DMF does not seem to play a relevant role in the case of alkaliactivated slags. The shape of the NMR spectra of the dissolution residue is close to those reported by Dyson et al. ${ }^{15}$

Figure 4(a) shows the ${ }^{29} \mathrm{Si}$ MAS NMR spectrum of $\mathrm{NaOH}$-activated slag after 1 day of hydration. We still observed the broad signal of anhydrous slag at around $-74 \mathrm{ppm}$. The decomposition obtained by subtracting the spectrum of the dissolution residue was not successful due to significant deviations between the experimental and the simulated data between -70 and $-100 \mathrm{ppm}$. The excess of the signal from the residue compared to the spectra of the unhydrated slag may indicate the presence of some hydration products altered by the dissolution process rather than an effect of the incongruent dissolution. This may be related to the aluminosilica gel observed in dissolution residues by Dyson et al. ${ }^{15}$ using transmission electron microscopy (TEM). The presence of this gel may also explain the appearance of the resonance at $57.5 \mathrm{ppm}$ in the ${ }^{27} \mathrm{Al} \mathrm{NMR}$ spectra of the residue (see Fig. 2). We can also note the presence of the signal of undissolved hydrotalcite-like phase at $9 \mathrm{ppm}$ in the ${ }^{27} \mathrm{Al}$ NMR spectrum of the residue. Better fits were obtained with the initial line shape of the anhydrous slag (see Fig. 2). These results indicate that the first dissolution method is preferential, although Dyson et al. ${ }^{15}$ did not find a meaningful fit in the case of hydrated slag cement blends. The analyses of blended cements may require fitting the additional peaks (from the $\mathrm{C}-\mathrm{S}-\mathrm{H}^{33}$ or from carbonation ${ }^{13}$ ) to obtain a satisfactory fit, rather than a modification of the slag peak shape.

For the following decomposition procedure, we assumed (i) that the line shape of the slag will not change with hydration time (i.e., congruent dissolution of the slag) and (ii) a pure Lorentzian shape for the $\mathrm{C}-\mathrm{S}-\mathrm{H}$ phase. ${ }^{34}$ The decomposition of the ${ }^{29} \mathrm{Si}$ NMR spectrum after subtraction of the signal of anhydrous slag is shown in Fig. 4(b). The signals of the $\mathrm{C}-\mathrm{S}-\mathrm{H}$ phase are well resolved. Both "manual" fitting

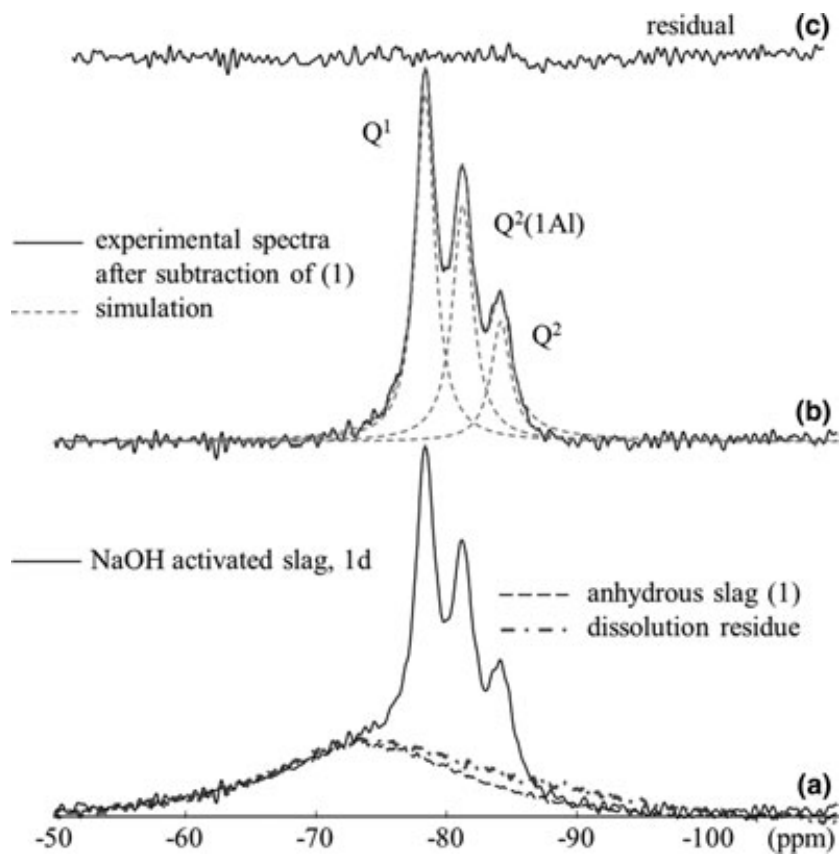

Fig. 4. ${ }^{29} \mathrm{Si}$ MAS NMR spectra of $\mathrm{NaOH}$-activated slag after 1 day of hydration with the spectra of anhydrous slag and dissolution residue (a), decomposition after subtraction of the signal from anhydrous slag of the $\mathrm{NaOH}$-activated slag spectra (b), difference plot between experimental and simulated data (c).
Table II. Calculated ${ }^{29}$ Si NMR Parameters (Positions, Full Width at Half Maximum FWHM, and Area) for Simulation of $\mathrm{NaOH}$ and WG-Activated Slag Spectra at 100 days

\begin{tabular}{|c|c|c|c|c|c|c|}
\hline \multirow[b]{2}{*}{$\mathrm{Q}^{n}$} & \multicolumn{2}{|c|}{ Center (ppm) } & \multicolumn{2}{|c|}{ FWHM (ppm) } & \multicolumn{2}{|c|}{ Area $(\%)$} \\
\hline & $\mathrm{NaOH}$ & WG & $\mathrm{NaOH}$ & WG & $\mathrm{NaOH}$ & WG \\
\hline $\mathrm{Q}^{0}$ & - & -75.8 & - & 3.9 & - & 5 \\
\hline $\mathrm{Q}^{1}$ & -78.7 & -78.7 & 2.1 & 2.7 & 35 & 22 \\
\hline $\mathrm{Q}^{2}(1 \mathrm{Al})$ & -81.5 & -81.5 & 2.4 & 2.7 & 39 & 31 \\
\hline $\mathrm{Q}^{2}$ & -84.5 & -84.5 & 2.0 & 2.7 & 26 & 42 \\
\hline
\end{tabular}

and automatic line-shape fitting with the positions, the FWHM, and the amplitudes as free parameters lead to similar results. The evaluated parameters are presented in Table II. We also simulated the rotational bands (Fig. 5), the intensities of which, relative to the central bands are higher for the anhydrous slag than for hydrated products. If the spinning sidebands are not taken into account in the simulation, an increase of up to $3 \mathrm{wt} \%$ in the $\mathrm{DOH}$ can be observed. The parameters for the line shape and line width of the rotational bands were set to those for the center bands. Their positions were deduced from the spinning rate so that only the intensities varied during the fit. Using higher spinning rates (e.g., on a $4-\mathrm{mm}$ probe) would be an alternative to avoid the simulation of rotational bands, ${ }^{35}$ but the drawback of such a change would be a considerably prolonged acquisition time.

The same procedure of line shape simulation has been used for the decomposition of the ${ }^{29} \mathrm{Si}$ NMR spectra of the WG-activated slag (Fig. 6). Owing to the considerably broadened resonances, spurious results were obtained when all three parameters (position, FWHM, and amplitude) were fitted simultaneously. Constraints in the positions of the peak have been added and the FWHM was increased slightly. The

residual

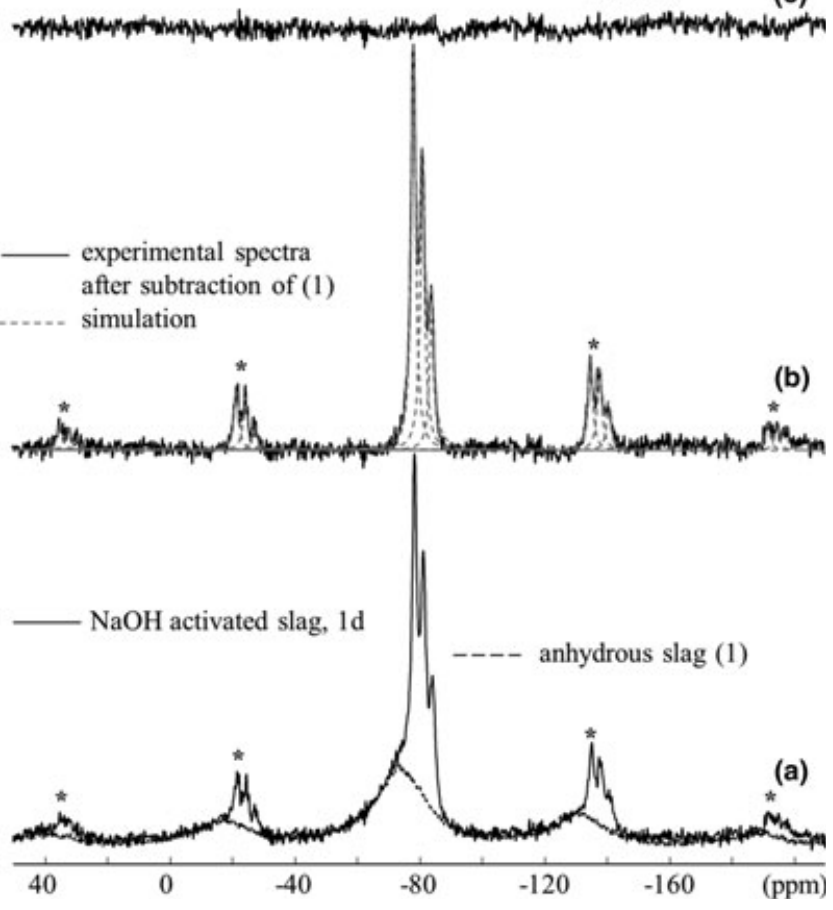

Fig. 5. ${ }^{29} \mathrm{Si}$ MAS NMR spectra, including rotational bands of $\mathrm{NaOH}$-activated slag at 1 day of hydration with the spectra of anhydrous slag and dissolution residue (a), decomposition after subtraction of the signal from anhydrous slag of the WG-activated slag spectra (b), difference plot between experimental and simulated spectra (c). 


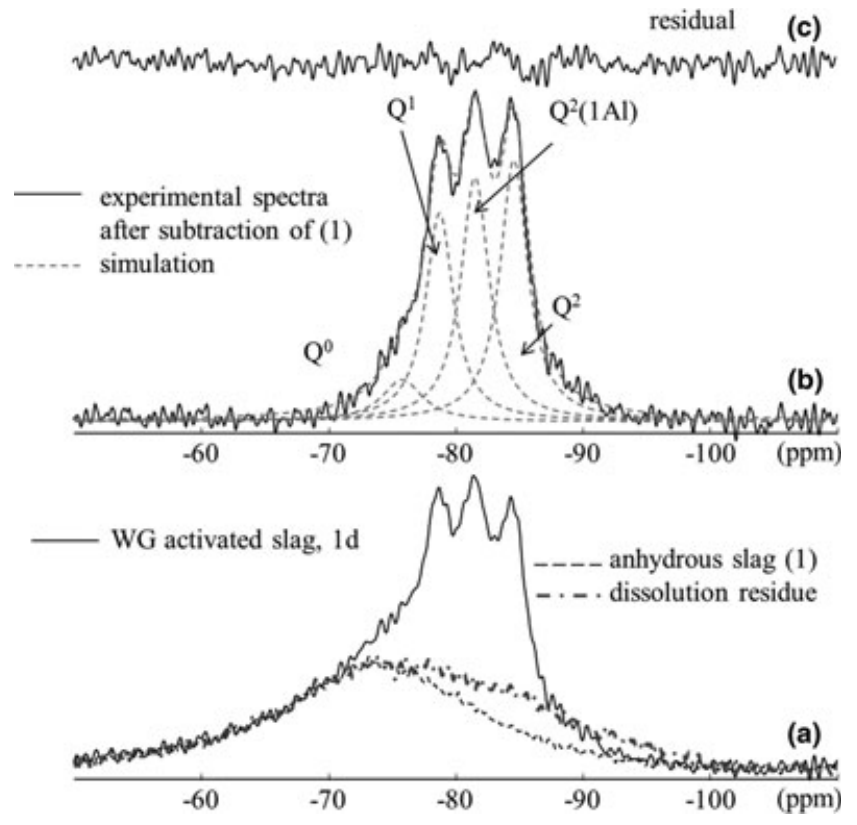

Fig. 6. ${ }^{29} \mathrm{Si}$ MAS NMR spectra of WG-activated slag at 1 day of hydration with the spectra of anhydrous slag and dissolution residue (a), decomposition after subtraction of the signal from anhydrous slag of the WG-activated slag spectra (b), difference plot between experimental and simulated spectra (c).

simulation required the fit of an additional resonance at around $-75.8 \mathrm{ppm}$ which may be attributed to hydrated monomeric silicate tetrahedra or $\mathrm{Q}_{1}(1 \mathrm{Al}) .{ }^{36}{ }^{29} \mathrm{Si}$ cross-polarization MAS NMR experiments on samples containing fewer paramagnetic species would be needed to confirm this signal assignment. The relative intensity of this species remains low in the samples and depends on the way the operator performs the zero and first-order phasing during NMR data treatment.

\section{(3) Degree of Hydration of the Slag Using ${ }^{29}$ Si NMR and SEM-IA}

The DOH obtained by ${ }^{29} \mathrm{Si}$ NMR and SEM-IA are presented in Table III and a graphical comparison of the DOH is shown in Fig. 7. Both methods indicate a very fast early reaction of the alkali-activated slag. The measured DOH of the slag is similar for both activators. The DOHs deduced from NMR and SEM-IA typically agree within $\sim 3 \%$ error of both measurement techniques. In general, the difference in $\mathrm{DOH}$ is in range of $2-3 \%$, the biggest difference $(5 \%)$ is observed for the WG-activated slag after 7 days (Table III). The good agreement between the two techniques shows the importance of preparing SEM samples that are free of microcracks.
The SEM-IA was also used to determine HOD, and the technique requires the user to verify the accuracy of the segmentation process. The combination of filters and gray level thresholding to distinguish the unreacted slag and the hydrated phases yield results that agree well with the NMR results. This independent consistency suggests that both techniques are accurate.

We can also assume that the relative high concentration of paramagnetic species in the slag had no significant impact on the technique but further work is needed to determine the influence of iron in the slag on the final quantitation results.

\section{(4) $C-S-H$ Composition Using ${ }^{29}$ Si NMR and SEM-EDX} Previous studies using XRD and SEM-EDX have shown the presence of two types of $\mathrm{C}-\mathrm{S}-\mathrm{H}$ in the case of $\mathrm{NaOH}$ activator and one type of $\mathrm{C}-\mathrm{S}-\mathrm{H}$ for the WG activator. ${ }^{3,4}$ The NMR analysis indicates the presence of only one "mean" $\mathrm{C}-\mathrm{S}-\mathrm{H}$ type. The $\mathrm{Al} / \mathrm{Si}$ atomic ratio deduced by ${ }^{29} \mathrm{Si} \mathrm{NMR}$ is slightly smaller than the ratio determined by SEM-EDX. The ${ }^{29} \mathrm{Si}$ NMR analysis can potentially overestimate or underestimate the $\mathrm{Al} / \mathrm{Si}$ atomic ratio. The $\mathrm{C}-\mathrm{S}-\mathrm{H}$ is composed of silicate chains that are kinked with repeat intervals of three $\mathrm{SiO}_{4}$ tetrahedra (dreierketten chains). In each interval of three tetrahedral $\mathrm{SiO}_{4}$, two are linked to the $\mathrm{Ca}-\mathrm{O}$ sheet. As reported by Richardson et al., ${ }^{37}$ aluminum enters the tetrahedral chains by substitution for the third or bridging tetrahedra $\mathrm{Q}_{2}{ }^{\mathrm{B}}$, which is not linked to the central $\mathrm{Ca}-\mathrm{O}$ part of the layer. As shown in Table III, C-S-H with mean chain length of 8 and $\mathrm{Al}$ to $\mathrm{Si}$ ratio of 0.15 were present in the WG-activated slag. A mean chain length of 8 implies a $\mathrm{C}-\mathrm{S}-\mathrm{H}$ composed in average of $2 \mathrm{Q}^{1}, 4 \mathrm{Q}^{2}$, and two bridging $\mathrm{Q}^{2}$, and an average $\mathrm{Al}$ to $\mathrm{Si}$ atomic ratio of $1 / 3$ in this $\mathrm{C}-\mathrm{S}-$ $\mathrm{H}$. The measured $\mathrm{Al} / \mathrm{Si}$ atomic ratio of 0.15 obtained by NMR and SEM-EDX indicates that not all the bridging sites are occupied by Al. As the ${ }^{29} \mathrm{Si}$ NMR chemical shift of the $\mathrm{Q}^{2}(1 \mathrm{Al})$ is in the same range as the $\mathrm{Q}_{2}{ }^{\mathrm{B}}$ (ranging from -80 to $-82 \mathrm{ppm}^{38}$ and from -81.5 to $-83 \mathrm{ppm}^{33,34}$ respectively), the intensity of the peak assigned to $\mathrm{Q}^{2}(1 \mathrm{Al})$ may contain some signals from $\mathrm{Q}^{2}(1 \mathrm{Al})$ and $\mathrm{Q}_{2}{ }^{\mathrm{B}}$. The calculation in Table III is based on the $\mathrm{Q}^{2}(1 \mathrm{Al})$ assignment, and so, the $\mathrm{Al} /$ $\mathrm{Si}$ atomic ratio may be overestimated. Conversely, as stressed by Andersen et al.," ${ }^{39}$ the SEM-EDX method does not distinguish between $\mathrm{Al}$ in fourfold and sixfold coordination in the $\mathrm{C}-\mathrm{S}-\mathrm{H}$, whereas ${ }^{29} \mathrm{Si}$ NMR provides the $\mathrm{Al}(\mathrm{IV})$ to $\mathrm{Si}$ ratio. As it is not yet clear if $\mathrm{Al}(\mathrm{VI})$ belongs to the $\mathrm{C}-\mathrm{S}-\mathrm{H}$, the $\mathrm{Al} /$ $\mathrm{Si}$ atomic ratio may be underestimated by NMR analysis.

However, there are also errors in the $\mathrm{Al} / \mathrm{Si}$ ratios estimated from the SEM-EDX analyses. As shown by Richardson et al., ${ }^{40}$ some significant differences can occur between SEMEDX and TEM-EDX analyses as different hydration products are intermixed in volumes that are much smaller than the interaction volume in the SEM.

Table III. Ca/Si, Ca/(Al + Si), and Al/Si Atomic Ratios for $\mathrm{C}-\mathrm{S}-\mathrm{H}$ and $\mathrm{Mg} / \mathrm{Al}$ Ratio for Hydrotalcite-Like Phase Obtained Using SEM-EDX Analysis, Al/Si Atomic Ratio and Mean Chain Length (CL) for C-S-H Obtained from ${ }^{29} \mathrm{Si}$ NMR and Degree of Hydration Determined Using SEM-IA Analysis and ${ }^{29} \mathrm{Si}$ NMR

\begin{tabular}{|c|c|c|c|c|c|c|c|c|c|}
\hline Activator & Time (days) & $\mathrm{Ca} / \mathrm{Si}$ & $\begin{array}{c}\mathrm{Ca} /(\mathrm{Al}+\mathrm{Si}) \\
\mathrm{SEM} \pm 0.05\end{array}$ & $\mathrm{Mg} / \mathrm{Al}$ & \multicolumn{2}{|c|}{$\mathrm{Al} / \mathrm{Si}$} & $\begin{array}{c}\mathrm{CL} \\
\mathrm{NMR} \pm 0.3\end{array}$ & \multicolumn{2}{|c|}{$\mathrm{DOH}$} \\
\hline \multirow[t]{3}{*}{$\mathrm{NaOH}$} & 1 & 0.89 & 0.77 & 2.08 & 0.15 & 0.18 & 5.1 & 44 & 47 \\
\hline & 28 & 0.90 & 0.77 & 2.04 & 0.17 & 0.19 & 6.3 & 52 & 55 \\
\hline & 100 & 0.88 & 0.75 & 2.06 & 0.17 & 0.19 & 6.7 & 56 & 59 \\
\hline \multirow[t]{2}{*}{ WG } & 1 & 0.82 & 0.71 & 1.98 & 0.15 & 0.17 & 8.0 & 40 & 41 \\
\hline & 100 & 0.82 & 0.71 & 1.97 & 0.15 & 0.17 & 9.2 & 54 & 53 \\
\hline
\end{tabular}




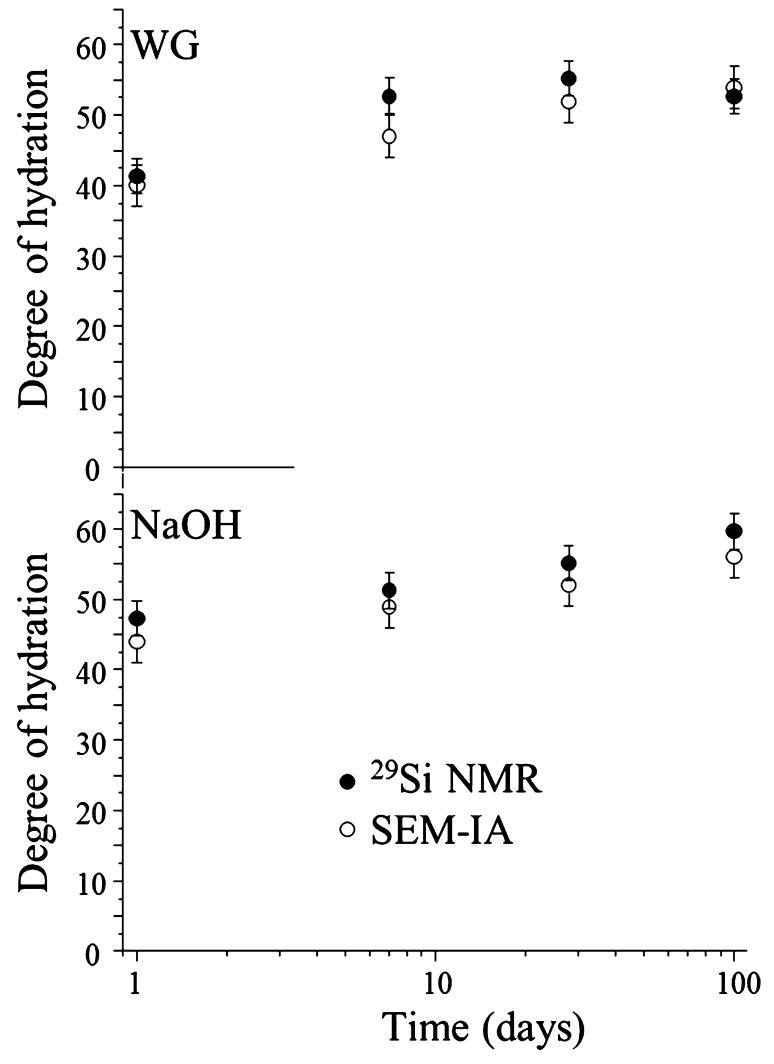

Fig. 7. Degree of hydration of the slag calculated using SEM-IA and ${ }^{29} \mathrm{Si}$ NMR as a function of hydration time.

\section{Conclusions}

The difference in the degree of hydration determined using ${ }^{29} \mathrm{Si}$ NMR and SEM-IA is within the error bars $( \pm 2.5$ and \pm 3 for NMR and SEM-IA, respectively), whereas the degree of hydration obtained using selective dissolution experiments is known to give poor results due to the presence of insoluble hydrotalcite-like phase and the formation of an aluminosilicate gel.

Two different methods, based on the decomposition of the ${ }^{29} \mathrm{Si}$ NMR spectra of blended cements have been proposed by Dyson et al. ${ }^{15}$ to obtain the degree of hydration of slag. The first method involves the fitting of residual slag using the spectrum of an anhydrous slag. The second method involves the fitting of residual slag using the spectrum of the dissolution residue to represent the peak shape. In the present study, these two methods have been applied to a less complex system, alkali-activated slag. The fitting of residual slag using an anhydrous slag spectrum gives satisfactory estimates for the degree of hydration and the $\mathrm{Al} / \mathrm{Si}$ atomic ratio of the $\mathrm{C}-\mathrm{S}-\mathrm{H}$, which are in agreement with SEM-IA and SEM-EDX analyses. The second method involving chemical extraction with or without DMF leads to problems in the decomposition that may be explained by the presence of hydration products altered by the selective dissolution process. The first method is thus recommended also for the decomposition of blended cement that contains slag, although some additional peak may be necessary in the decomposition process as observed in the case of WG activator.

\section{Acknowledgments}

The authors thank K.A. Snyder (NIST) for valuable comments, D. Rentsch (Empa, Laboratory for Functional Polymers) for his support during the NMR experiments, and B. Ingold for polishing samples for SEM analysis.

\section{References}

${ }^{1}$ E. Gartner, "Industrially Interesting Approaches to "Low- $\mathrm{CO}_{2}$ " Cements," Cem. Concr. Res., 34, 1489-98 (2004).
${ }^{2}$ M. C. G. Juenger, F. Winnefeld, J. L. Provis, and J. H. Ideker, "Advances in Alternative Cementitious Binders," Cem. Concr. Res., in press, doi: 10.1016/ j.cemconres.2010.11.012.

${ }^{3}$ M. Ben Haha, B. Lothenbach, G. Le Saout, and F. Winnefeld, "Influence of Slag Chemistry on the Hydration of Alkali-Activated Blast-Furnace SlagPart I: Effect of MgO," Cem. Concr. Res., 41, 955-63 (2011).

${ }^{4} \mathrm{M}$. Ben Haha, G. Le Saout, F. Winnefeld, and B. Lothenbach, "Influence of Activator Type on Hydration Kinetics, Hydrate Assemblage and Microstructural Development of Alkali Activated Blast-Furnace Slags," Cem. Concr. Res., 41, 301-10 (2011).

${ }^{5}$ I. G. Richardson, A. R. Brough, G. W. Groves, and C. M. Dobson, "The Characterization of Hardened Alkali-Activated Blast-Furnace Slag Pastes and the Nature of the Calcium Silicate Hydrate (C-S-H) Phase.," Cem. Concr. Res., 24, 813-29 (1994).

${ }^{6}$ S. Song and H. M. Jennings, "Pore Solution Chemistry of Alkali-Activated Ground Granulated Blast-Furnace Slag," Cem. Concr. Res., 29, 159-70 (1999).

${ }^{7}$ S.-D. Wang and K. L. Scrivener, ${ }^{29} \mathrm{Si}$ and ${ }^{27} \mathrm{Al}$ NMR Study of AlkaliActivated Slag," Cem. Concr. Res., 33, 769-74 (2003).

${ }^{8}$ J. E. Oh, P. J. M. Monteiro, S. S. Jun, S. Choi, and S. M. Clark, "The Evolution of Strength and Crystalline Phases for Alkali-Activated Ground Blast Furnace Slag and Fly Ash-Based Geopolymers," Cem. Concr. Res., 40, 189-96 (2010).

${ }^{9}$ K. Luke and F. P. Glasser, "Selective Dissolution of Hydrated Blast Furnace Slag Cements.," Cem. Concr. Res., 17, 273-82 (1987).

${ }^{10}$ J. S. Lumley, R. S. Gollop, G. K. Moir, and H. F. W. Taylor, "Degrees of Reaction of the Slag in Some Blends with Portland Cements," Cem. Concr. Res., 26, 139-51 (1996).

${ }^{11}$ R. Taylor, I. G. Richardson, and R. M. D. Brydson, "Composition and Microstructure of 20-Year-old Ordinary Portland Cement-Ground Granulated Blast-Furnace Slag Blends Containing 0 to $100 \%$ Slag," Cem. Concr. Res., 40, 971-83 (2010).

${ }^{12}$ F. Brunet, T. Charpentier, C. N. Chao, H. Peycelon, and A. Nonat, "Characterization by Solid-State NMR and Selective Dissolution Techniques of Anhydrous and Hydrated CEM V Cement Pastes," Cem. Concr. Res., 40, 208-19 (2010).

${ }^{13}$ A. R. Brough and A. Atkinson, "Sodium Silicate-Based, Alkali-Activated Slag Mortars Part I. Strength, Hydration and Microstructure," Cem. Concr. Res., 32, 865-79 (2002).

${ }^{14}$ M. B. Haha, K. De Weerdt, and B. Lothenbach, "Quantification of the Degree of Reaction of Fly Ash," Cem. Concr. Res., 40, 1620-9 (2010).

${ }^{15}$ H. M. Dyson, I. G. Richardson, and A. R. Brough, "A Combined ${ }^{29} \mathrm{Si}$ MAS NMR and Selective Dissolution Technique for the Quantitative Evaluation of Hydrated Blast Furnace Slag Cement Blends," J. Am. Ceram. Soc., 90, 598-602 (2007).

${ }^{16}$ H. S. Pietersen, A. P. M. Kentgens, G. H. Nachtegaal, W. S. Veeman, and J. M. Bijen, "The Reaction Mechanism of Blended Cements: A ${ }^{29}$ Si NMR Study"; pp. 795-812 in Fourth International Conference on Fly Ash, Silica Fume, Slag and Natural Pozzolans in Concrete, Vol. 1, Edited by V. M. Malhotra, American Concrete Institute, Istanbul, Turkey, 1993.

${ }^{17} \mathrm{H}$. Hilbig and A. Buchwald, "The Effect of Activator Concentration on Reaction Degree and Structure Formation of Alkali-Activated Ground Granulated Blast Furnace Slag," J. Mater. Sci., 41, 6488-91 (2006).

${ }^{18}$ M. Regourd, J. H. Thomassin, P. Baillif, and J. C. Touray, "BlastFurnace Slag Hydration. Surface Analysis,” Cem. Concr. Res., 13, 549-56 (1983).

${ }^{19}$ R. Dron and F. Brivot, "Approche du Problème de la Réactivité du Laitier Granule"; pp. III-134-9 in 7th International Congress on the Chemistry of Cement, Vol. 2, Communications. Editions Septima, Paris, 1980.

${ }^{20}$ D. Massiot, F. Fayon, M. Capron, I. King, S. Le Calvé, B. Alonso, J.-P. Durand, B. Bujoli, Z. Gan, and G. Hoatson, "Modelling One- and TwoDimensional Solid-State NMR Spectra," Magn. Reson. Chem., 40, 70-6 (2002).

${ }^{21}$ E. Demoulian, C. Vernet, F. Hawthorn, and P. Gourdin, "Détermination de la teneur en laitier dans les ciments par dissolutions sélectives"; pp. III1516 in 7th International Congress on the Chemistry of Cement, Vol. 2, Communications. Editions Septima, Paris, 1980.

${ }^{22}$ K. Luke and F. P. Glasser, "Internal Chemical Evolution of the Constitution of Blended Cements," Cem. Concr. Res., 18, 495-502 (1988).

${ }^{23}$ K. L. Scrivener, T. Füllmann, E. Gallucci, G. Walenta, and E. Bermejo, "Quantitative Study of Portland Cement Hydration by X-ray Diffraction/Rietveld Analysis and Independent Methods," Cem. Concr. Res., 34, 1541-7 (2004).

${ }^{24}$ K. L. Scrivener, "Backscattered Electron Imaging of Cementitious Microstructures: Understanding and Quantification," Cem. Concr. Comp., 26, 93545 (2004).

${ }^{25}$ M. B. Haha, E. Gallucci, A. Guidoum, and K. L. Scrivener, "Relation of Expansion due to Alkali Silica Reaction to the Degree of Reaction Measured by SEM Image Analysis," Cem. Concr. Res., 37, 1206-14 (2007).

${ }^{26} \mathrm{P}$. J. Schilling, L. G. Butler, A. Roy, and H. C. Eaton, ${ }^{29}{ }^{29} \mathrm{Si}$ and ${ }^{27} \mathrm{Al}$ MAS-NMR of NaOH-Activated Blast-Furnace Slag," J. Am. Ceram. Soc., 77, 2363-8 (1994).

${ }^{27}$ F. Bonk, J. Schneider, M. A. Cincotto, and H. Panepucci, "Characterization by Multinuclear High-Resolution NMR of Hydration Products in Activated Blast-Furnace Slag Pastes," J. Am. Ceram. Soc., 86, 1712-9 (2003).

${ }^{28}$ M. Bellotto, B. Rebours, O. Clause, J. Lynch, D. Bazin, and E. Elkaïm, "A Reexamination of Hydrotalcite Crystal Chemistry," J. Phys. Chem., 100, 8527-34 (1996)

${ }^{29}$ G. Renaudin, J. Russias, F. Leroux, C. Cau-dit-Coumes, and F. Frizon, "Structural Characterization of C-S-H and C-A-S-H Samples-Part II: Local Environment Investigated by Spectroscopic Analyses," J. Solid State Chem., 182, 3320-9 (2009). 
${ }^{30}$ M. D. Andersen, H. J. Jakobsen, and J. Skibsted, "Incorporation of Aluminium in the Calcium Silicate Hydrate (C-S-H) of Hydrated Portland Cements: A High-Field ${ }^{27} \mathrm{Al}$ and ${ }^{29} \mathrm{Si}$ NMR Investigation," Inorg. Chem., 42, 2280-7 (2003).

${ }^{31}$ J. Skibsted and H. J. Jakobsen, "Characterization of the Calcium Silicate and Aluminate Phases in Anhydrous and Hydrated Portland Cements by ${ }^{27} \mathrm{~A}$ and ${ }^{29} \mathrm{Si}$ MAS NMR Spectroscopy"; pp. 3-45 in Nuclear Magnetic Resonance Spectroscopy of Cement-Based Materials, Edited by P. Colombet, A.-R. Grimmer, H. Zanni, and P. Sozzani, Springer, Berlin, 1998.

${ }^{32}$ J. Schneider, M. A. Cincotto, and H. Panepucci, “29 Si and ${ }^{27}$ Al High-Resolution NMR Characterization of Calcium Silicate Hydrate Phases in Activated Blast-Furnace Slag Pastes," Cem. Concr. Res., 31, 993-1001 (2001).

${ }^{33}$ F. Brunet, P. Bertani, T. Charpentier, A. Nonat, and J. Virlet, "Application of ${ }^{29} \mathrm{Si}$ Homonuclear and ${ }^{1} \mathrm{H}^{29} \mathrm{Si}$ Heteronuclear NMR Correlation to Structural Studies of Calcium Silicate Hydrates," J. Phys. Chem. B, 108, 15494-502 (2004).

${ }^{34}$ I Klur, B. Pollet, J Virlet, and A Nonat "C-S-H Structure Evolution with Calcium Content by Multinuclear NMR"; pp. 119-41 in Nuclear Magnetic Resonance Spectroscopy of Cement-Based Materials, Edited by P. Colombet, A.-R. Grimmer, H. Zanni, and P. Sozzani, Springer, Berlin, 1998.
${ }^{35}$ S. Poulsen, V. Kocaba, G. Le Saout, H. J. Jakobsen, K. L. Scrivener, and J. Skibsted, "Improved Quantification of Alite and Belite in Anhydrous Portland Cements by ${ }^{29} \mathrm{Si}$ MAS NMR: Effects of Paramagnetic Ions," Solid State NMR, 36, 32-44 (2009).

${ }^{36}$ S. Murgier, H. Zanni, and D. Gouvenot, "Blast Furnace Slag Cement: A ${ }^{29} \mathrm{Si}$ and ${ }^{27}$ Al NMR Study," C.R. Chimie, 7, 389-94 (2004).

${ }^{7}$ I. G. Richardson, A. R. Brough, R. Brydson, G. W Groves, and C. M. Dobson, "Location of Aluminium in Substituted Calcium Silicate Hydrate (C-S-H) Gels as Determined by ${ }^{29} \mathrm{Si}$ and ${ }^{27} \mathrm{Al}$ NMR and EELS," J. Am. Ceram. Soc., 76, 2285-8 (1993).

${ }^{38}$ S. Komarneni, R. Roy, D. M. Roy, C. A. Fyfe, G. J. Kennedy, A. A. Bothner-by, J. Dadok, and A. S. Chesnick, " ${ }^{27} \mathrm{Al}$ and ${ }^{29} \mathrm{Si}$ Magic Angle Spinning Nuclear Magnetic Resonance Spectroscopy of Al-Substituted Tobermorites," J. Mater. Sci., 20, 4209-14 (1985).

${ }^{39}$ M. D. Andersen, H. J. Jakobsen, and J. Skibsted, "A New AluminiumHydrate Species in Hydrated Portland Cements Characterized by ${ }^{27} \mathrm{Al}$ and ${ }^{29} \mathrm{Si}$ MAS NMR Spectroscopy," Cem. Concr. Res., 36, 3-17 (2006).

${ }^{40}$ I. G. Richardson, J. Skibsted, L. Black, and R. J. Kirkpatrick, "Characterisation of Cement Hydrate Phases by TEM, NMR and Raman Spectroscopy," Adv. Cem. Res., 22, 233-48 (2010). 